Arch. histol. jap. Vol. 30, No. 3 (1969) p. $315-320$

Department of Anatomy (Prof. Y. SANo), Kyoto Prefectural University of Medicine, Kyoto, Japan

\title{
Fluorescence Microscopic Findings on the Otic and Pterygopalatine Ganglia of the Dog
}

\author{
Yutaka Sano, Hitoshi YoshiKawa, Masao Konishi and Junzo OchI \\ (佐野 豊, 吉川検, 小西理雄, 越智淳三)
}

Received December 13, 1968

\section{Introduction}

Since the first investigation on the distribution of catecholamines in the cytoplasm of sympathetic ganglion cells of the rat (ЕRÄNKÖ and HÄrKÖNEN 1963), histochemical fluorescence microscopic observations have been carried out on the ciliary (Ehinger 1967, Huikuri 1966), trigeminal (SANTini 1966), spinal (Owman and SANTini 1966) and enteric ganglia (Norberg 1964, HaMBERger and Norberg 1965). However, up to date there seems to be no report on the distribution of catecholamines in the otic and pterygopalatine ganglia. The present study attempts a histochemical examination of these two ganglia of the dog, using fluorescence microscopy.

\section{Material and Methods}

The otic and pterygopalatine ganglia of the dog were used. Eight dogs were sacrificed: two of them were untreated, four of them were given either reserpine or nialamide, and two of them received an operation of upper thoracic sympathetic ganglionectomy under pentobarbital anesthesia (Table 1). The superior cervical

Table 1

\begin{tabular}{lccc}
\hline Treatment & Number of dogs used & $\begin{array}{c}\text { Dose } \\
(\mathrm{mg} / \mathrm{kg} \text { body wt. })\end{array}$ & $\begin{array}{c}\text { Time before } \\
\text { killing }\end{array}$ \\
\hline Untreated & 2 & - & - \\
Reserpine i.p. & 2 & 10 & $24 \mathrm{hrs}$ \\
$\begin{array}{l}\text { Nialamide i.p. } \\
\begin{array}{l}\text { Upper thoracic and } \\
\text { cervical sympathetic } \\
\text { ganglionectomy }\end{array}\end{array}$ & 2 & 500 & $6 \mathrm{hrs}$ \\
\hline
\end{tabular}

ganglion of each animal, except in the operated cases, was also used as a control for the examination of the specific fluorescence. All specimens were dissected under light ether or thiopenthal sodium anesthesia. Following the method of FALCK and OWMAN (1965), the specimens were rapidly frozen in an isopentane dry ice mixture 
and were kept in vacuo for 7 days at a temperature of $-35^{\circ} \mathrm{C}, 1$ day at $-20^{\circ} \mathrm{C}, 12$ hrs at $+35^{\circ} \mathrm{C}$ and $1 \mathrm{hr}$ at $60^{\circ} \mathrm{C}$. After freeze-drying, the specimens were transferred to a glass bottle containing $6 \mathrm{~g}$ of granular paraformaldehyde (HAMBERGER et al. 1965), and the bottle was placed in an incubator at a temperature of $80^{\circ} \mathrm{C}$ for $1 \mathrm{hr}$. The specimens were then infiltrated with paraffin (m.p. $53.5^{\circ} \mathrm{C}$ ) in vacuo for $15 \mathrm{~min}$. Sections were made at $8 \mu$ thickness and mounted in liquid paraffin after removal of paraffin by xylene. The preparations were studied with an Ultraphot II (Zeiss) equipped with an HBO 200 high pressure mercury lamp, a $3 \mathrm{~mm}$ BG 12 exitation filter, a dark field condenser for immersion oil, and a $500 \mathrm{~m} \mu$ barrier filter. After examination and photography with the fluorescence microscope, the sections were reexamined in the converted phase-contrast microscope. The same tissue sections were stained with hematoxylin-eosin or toluidin blue for identefication and localization of fluorescenct materials.

\section{Observations}

\section{A. Normal animals}

\section{Superior cervical ganglion}

The superior cervical ganglion of the normal dog displayed the yellow-green, monoamine-specific fluorescence of various intensities in the cytoplasma of many ganglion cells and the pericellular apparatus formed by numerous nerve terminals (Fig. 1).

2. Otic and pterygopalatine ganglia

Little difference could be recognized in the fluorescnece microscopic findings

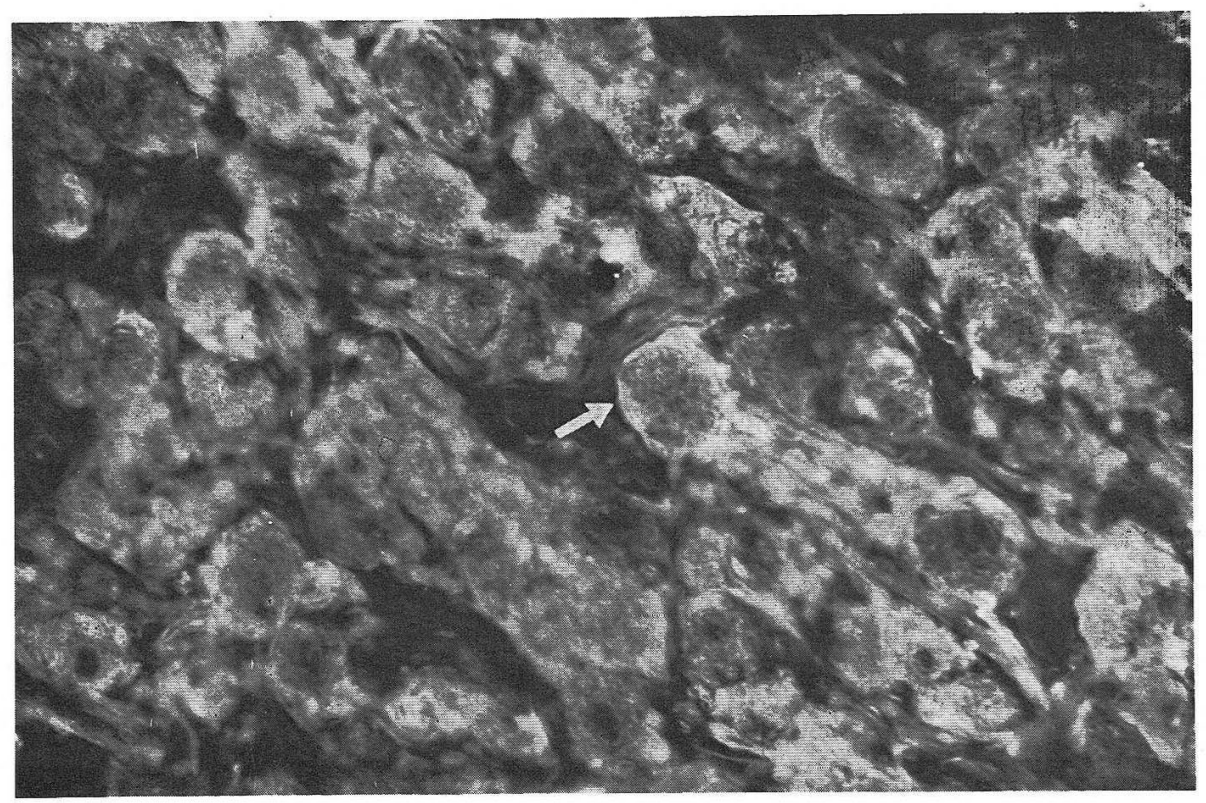

Fig. 1. Superior cervical ganglion, dog, untreated. Adrenergic cell bodies of varying fluorescence intensities are seen. Intensely fluorescent varicose terminals are seen around the fluorescent cell body, and form a basket-like synaptic structure $(\nearrow) . \quad \times 340$ 


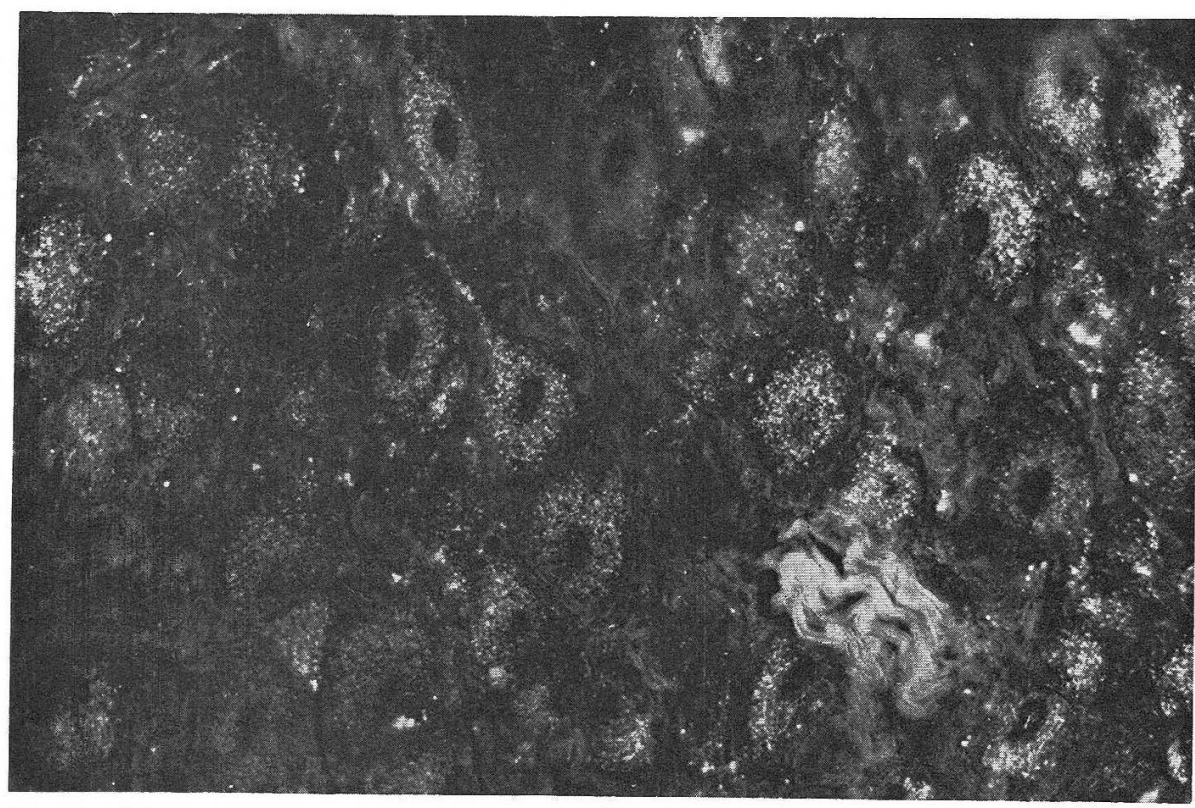

Fig. 2. Otic ganglion, dog, untreated. Nerve cell bodies of highly varying autofluorescence intensities are seen and a few are completely devoid of autofluorescence. Between the nerve cells are seen the shadows of non-fluorescent nerve processcs. Moderately autofluorescent connective tissue is seen among the cell clusters. No adrenergic nerve terminals around or among the nerve cells could be found. $\times 380$

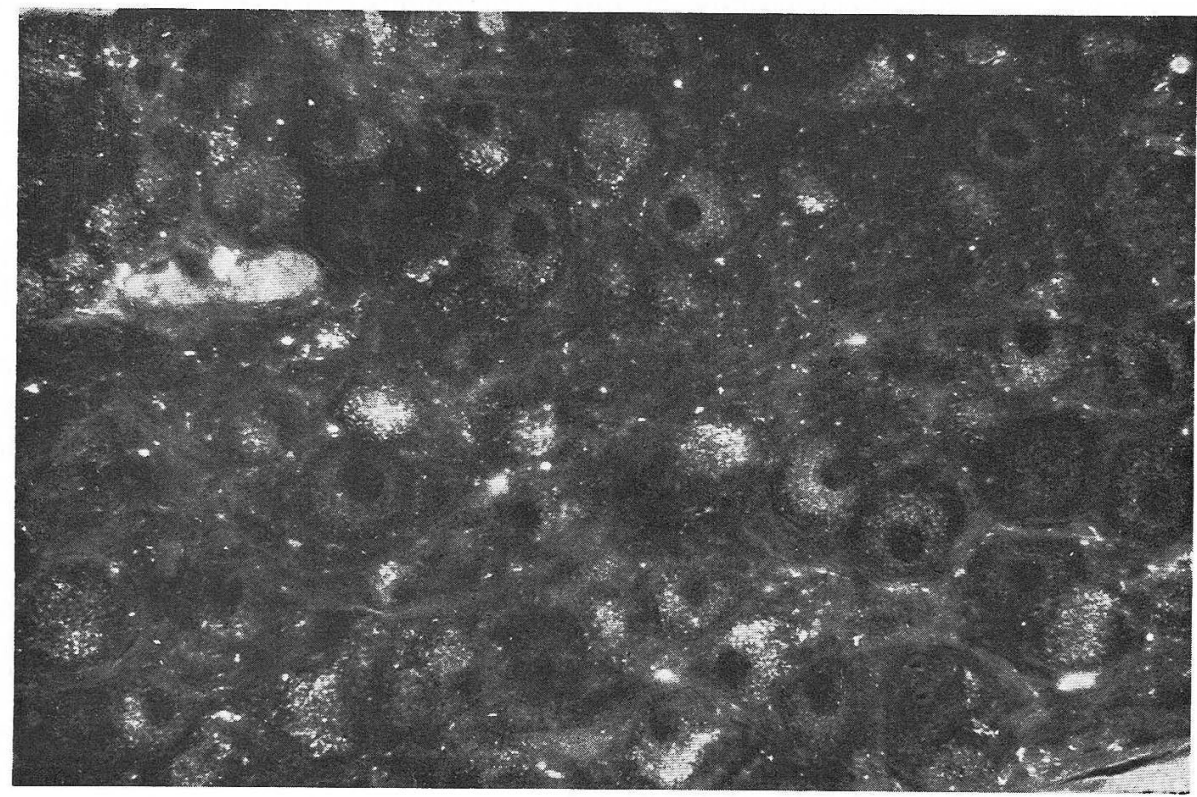

Fig. 3. Pterygopalatine ganglion, dog, untreated. The nerve cell bodies exhibit not the yellow-green catecholamine fluorescence but a yellow-brown autofluorescence. The nuclei are essentially non-fluorescent. No adrenergic nerve terminals could be found among and around the nerve cells. $\times 320$ 
between the otic and pterygopalatine ganglia, except for the size of ganglion itself and the amount of connective tissue contained (Fig. 2, 3). The nerve cells were round or oval in shape and varied considerably in size, with diameters ranging from 20 to $40 \mu$. Their nuclei were located centrally or eccentrically in the cells. Nerve cells with specific fluorescence were never found within both ganglia. Almost all nerve cells, however, showed a diffuse yellow-brown fluorescence of various intensities in their perikarya. This fluorescence was considerably intense in a few of the cells, though more or less weak in most of them. There were also some cells completely devoid of this type of fluorescence.

No fluorescent nerve varicosities suggesting adrenergic nerve terminals could be detected in both ganglia. A weak diffuse green autofluorescence was noted in the connective tissue which divided the ganglion cell groups and contained blood capillaries. Apart from this connectiv tissue septum only a few green autofluorescent fiber-like structures were recognized among the ganglion cells.

\section{B. Treated dogs}

\section{Superior cervical ganglion}

Between nialamide-treated dog and reserpinized dog there was a remarkable difference in the fluorescence appearance in the perikarya of the ganglion cells and at the preganglionic nerve terminals around them: The intensity of the fluorescence in these sites was considerably raised by nialamide, whereas it was extremely lowered by reserpine.

\section{Otic and pterygopalatine ganglia}

The results in the treated animals scarcely differed from those of the untreated animals with regard to these ganglia. Different treatments caused no distinct differences in the appearance of fluorescence.

\section{Discussion}

Postganglionic sympathetic fibers originating from the superior cervical sympathetic ganglion pass through four cephalic autonomic ganglia, i.e., the ciliary, otic, pterygopalatine and submaxillary ganglia, as branches from the plexus around the internal and external carotid arteries.

As mentioned above, we could find no monoamine-specific fluorescent neurons or nerve terminals in the otic and the pterygopalatine ganglia of the dog, though EHINGER (1967) had found fine varicose adrenergic fibers which terminated at the small ganglion cells in the avian ciliary ganglion. Thus, it was confirmed that sympathetic fibers from the superior cervical ganglion do not make neuron exchange in the canine otic and pterygopalatine ganglia. We could, however, give no sufficient fluorescence microscopic evidence for the classical description that postganglionic sympathetic fibers pass through the cephalic autonomic ganglia, since non-terminal sympathetic axons are very difficult to detect with fluorescence microscopy. The above-mentioned fluorescent fiber-like structures intermingled with connective tissue may be considered as unspecific, because they did not show any change between the untreated animals and those ipsilaterally resected of upper thoracic and cervical sympathetic ganglia, and also between reserpinized and nialamide-treated dogs. A yellow to brown diffuse fluorescence of varying intensities, developed in 
the cytoplasm of almost all neurons, was completely stable against the treatment with nialamide or reserpine. It was therefore certain that this fluorescence also is not due to catecholamines; its nature remains unknown.

\section{Summary}

The otic and pterygopalatine ganglia and, as controls, the superior cervical ganglia of the dog were studied by the histochemical fluorescence methed of FALCK and Hillarp.

Most nerve cells of the superior cervical ganglion contained monoamine specific fluorescent granules, and numerous monoaminergic terminals occurred among and around the neurons. There were, however, found neither adrenergic neurons nor adrenergic teminals in both the otic and the pterygopalatine ganglia in normal and even in nialamide-treated animals. A yellow-brown fluorescence of unknown nature, which did not disappear after the administration of reserpine as well as after cervical and upper thoracic sympathetic ganglionectomy, was found in the perikarya of nerve cells in these ganglia.

The findings obtained suggest that there is no adrenergic neuron in both the otic and the pterygopalatine ganglia, and that sympathetic fibers originating from the sympathetic trunk do not make neuron exchange in the two ganglia.

\section{イヌの耳および翼口蓋神経節の螢光顕微鏡的観察（内容自抄）}

イヌの耳㧍よび翼口蓋神経節ならびに刘照として上頸神経節が，FALCK-HILLARP 法に より䖝光顕微鏡で観察された.

モノアミン特有の黄緑色䖝光をもつ神経細胞および終末は，上頸神経節中には多数観 察されたが，耳および翼口蓋神経節中では全く認められなかった．しかし，後二者の神 経細胞の多くは，細胞体にレセルピン投与，頸・上胸部交感神経節摘除によっても消失 しない黄褐色の自家䖝光性顆粒を含有していた。 また，ナイアラマイドを投与しても， モノアミンの出現をみなかった。

以上のことから耳および翼口蓋神経節中には，アドレナリン作動性神経細胞はないと 考元られる。また，交感神経幹から上行する交感神経は，これらの神経節ではノイロン を交換しないものと結論できる.

\section{References}

Dixon, J. S.: The fine structure of parasympathetic nerve cells in the otic ganglia of the rabbit. Anat. Rec. $156:$ 239-251 (1966).

Ehinger, B.: Adrenergic nerves in the avian eye and ciliary ganglion. Z. Zellforsch. 82 : 577588 (1967).

Eränkö, O. and M. Härkönen : Histochemical demonstration of fluorogenic amines in the cytoplasm of sympathetic ganglion cell of the rat. Acta physiol. scand. 58:285-286 (1963).

Falck, B. and Ch. Owman : A detailed methodological description of the fluorescence method for the cellular demonstration of biogenic monoamines. Acta Univ. Lund II, 7:1-23 (1965). 
Hamberger, B., T. Malmfors and Ch. Sachs : Standarization of paraformaldehyde and of certain procedures for the histochemical demonstration of catecholamines. J. Histochem. Cytochem. $13: 143$ (1965).

Hamberger, B. and K.-A. Norberg : Studies on some systems of adrenergic synaptic terminals in the abdominal ganglia of the cat. Acta physiol. scand. 65 : 235-242 (1965).

Huikuri, T. : Histochemistry of the ciliary ganglion of the rat and the effect of pre- and postganglionic nerve division. Acta physiol. scand. 69 : 64-67 (1966).

Norberg, K.-A. : Adrenergic innervation of the intestinal wall studied by fluorescence microscopy. Int. J. Neuropharmacol. $3:$ 379-382 (1964).

Owman, Ch. and M. Santini : Adrenergic nerves in spinal ganglia of the cat. Acta physiol. scand. $68: 127-128$ (1966).

Santini, M. : Adrenergic fibers in the feline Gasserian ganglian. Life Sci. 5 : 283-287 (1966). 